\title{
Process Parameters for Influencing Polyhydroxyalkanoate Producing Bacterial Factories: An Overview
}

\author{
Amandeep Girdhar ${ }^{1 *}$, Mayuri Bhatia1, Sunil Nagpal ${ }^{2}$, Amol Kanampalliwar $^{1}$ and Archana Tiwari ${ }^{1}$
}

${ }^{1}$ School of Biotechnology, Rajiv Gandhi Proudyogiki Vishwavidhyalaya, State Technological University, Airport Bypass Road, Bhopal 426033, Madhya Pradesh, India ${ }^{2}$ Department of Biochemical Engineering, Indian Institute of Technology, Safdarganj Development Area, Hauz Khas, IIT Campus, New Delhi, Delhi 110016, India

\begin{abstract}
The ever increasing potentialities of petroleum plastics with respect to lack of degradation, inability to recycle and the toxic effects of incineration, has urged to design biodegradable polymers, often called Green Plastics. These biodegradable plastics are promiscuous due to their analogous properties and environmental friendliness. Bacterial factories and Plants being their natural sources for production made them a promiscuous solution. Fermentation is the procedural technology used with certain fillers that are known to enhance the chemo-mechanical properties. The process at the industrial level is not well accepted due to the certain lacunas. The review mainly focuses to assimilate a few researches that implicate the best known process parameters for Batch, Fed-batch, Continuous and Two stage modes of fermentation without compromising the downstream processing at commercial level.
\end{abstract}

Keywords: Polyhydroxyalkanoate; Bacteria; Carbon sources; Batch culture; Economy

\section{Introduction}

In the world of advancements today, almost every product is constituted of some kind of polymer. There is no doubt that the need for polymers and thus the products they constitute is ever increasing. Till date, these needs are being fulfilled by synthetic polymers (often called plastics), which are produced from petrochemicals [1] which makes them eco- 'unfriendly'. The inherent nature of petroleum derived products, calls for a serving approach, in the form of Biopolymerspolymers derived from living organisms/renewable resources [2]. To satisfy the consumers and get acceptability substitute needs to exhibit similar (if not identical) characteristics to the product being replaced and so it is for biopolymers while replacing the synthetic polymers properties, ranging from molecular weight, density, melting point, crystallinity, glass transition temperature to $\mathrm{O}_{2}$-permeability, UVresistance, resistance to solvents, tensile strength and elongation to break [3]. Fortunately, a special class of biopolymers called PHAs shows some of the extraordinary similarities to the well known synthetic polymers like polypropylene, polyethylene etc. [4], moreover, their biodegradability has made them renowned as biopolymers of today.

\section{History and chemical nature}

In 1920, a French microbiologist Maurice Lemoigne discovered a gram positive bacterium Bacillus megaterium [5] that accumulated intracellular granules of polyester called poly(3-hydroxybutyrate) [6]. Table 1 enlists different types of PHA.

PHAs are polymeric compounds biosynthesized by a variety of gram positive and gram negative bacteria [7], as carbon and energy reserves (often called carbonosomes) [8]. Structurally, R-hydroxyalkonic acids act as the monomeric form of PHAs.

\section{Natural sources of production}

Polyhydroxyalkanoates are produced in microbes. Although efforts have been made from plant cells through transgenics, but has not achieved much success because low yields of less than $10 \%(\mathrm{w} / \mathrm{w})$ of dry cell weight can be sustained whereas, high yield limits growth and development of plants $[9,10]$. On the other hand, PHAs can be accumulated upto $90 \%(\mathrm{w} / \mathrm{w})$ in bacterial cells [10] and are thus a priority because of the ease in culturing and economical, in contrast to the complex plant system [10].

\section{Bacterial Polymer Production}

PHAs accumulation is an inherent response to the stress conditions faced by bacterial cells $[11,12]$, these are generated in vitro by exposing bacteria to nutrient limitations, due to which they switch their metabolic pathways and cause PHA production as their carbon and energy reserves [13], to name a few of these substrates are bagasse [14], molasses [15,16], corn cob [14] and other agricultural wastes $[4,17]$ In fact significant PHA production has been reported among various bacterial strains when growing on kitchen waste [18], industrial wastes $[7,14,19]$, crude and edible oils as carbon sources [20-23]. The costing of these substrates is low or null, making the process cost effective at the upstream level. The Figures 1 and 2 depicts the biopolymer synthesis from bacteria.

PHA production has been reported in wide variety of bacterial

\begin{tabular}{|c|c|c|}
\hline PHAs & $\begin{array}{c}\text { Number of Carbon } \\
\text { Atoms in Monomers of } \\
\text { PHA }\end{array}$ & Examples \\
\hline $\begin{array}{c}\text { Short chain length PHAs (scl- } \\
\text { PHAs) }\end{array}$ & $3-5$ & $\begin{array}{c}\mathrm{P}(3 \mathrm{HB}) \\
\mathrm{P}(4 \mathrm{HB})\end{array}$ \\
\hline $\begin{array}{c}\text { Medium chain length PHAs } \\
\text { (mcl-PHAs) }\end{array}$ & $6-14$ & $\begin{array}{c}\mathrm{P}(3 \mathrm{HHx}) \\
\mathrm{P}(3 \mathrm{HO})\end{array}$ \\
\hline
\end{tabular}

Table 1: Types of PHAs [2].

*Corresponding author: Amandeep Girdhar, School of Biotechnology, Rajiv Gandhi Proudyogiki Vishwavidhyalaya, State Technological University, Airport Bypass Road, Bhopal 426033, Madhya Pradesh, India, Tel: +918989206617; E-mail: amangirdher@gmail.com

Received August 19, 2013; Accepted September 26, 2013; Published October 03,2013

Citation: Girdhar A, Bhatia M, Nagpal S, Kanampalliwar A, Tiwari A (2013) Process Parameters for Influencing Polyhydroxyalkanoate Producing Bacterial Factories: An Overview. J Pet Environ Biotechnol 4: 155. doi:10.4172/2157-7463.1000155

Copyright: @ 2013 Girdhar A, et al. This is an open-access article distributed under the terms of the Creative Commons Attribution License, which permits unrestricted use, distribution, and reproduction in any medium, provided the original author and source are credited. 

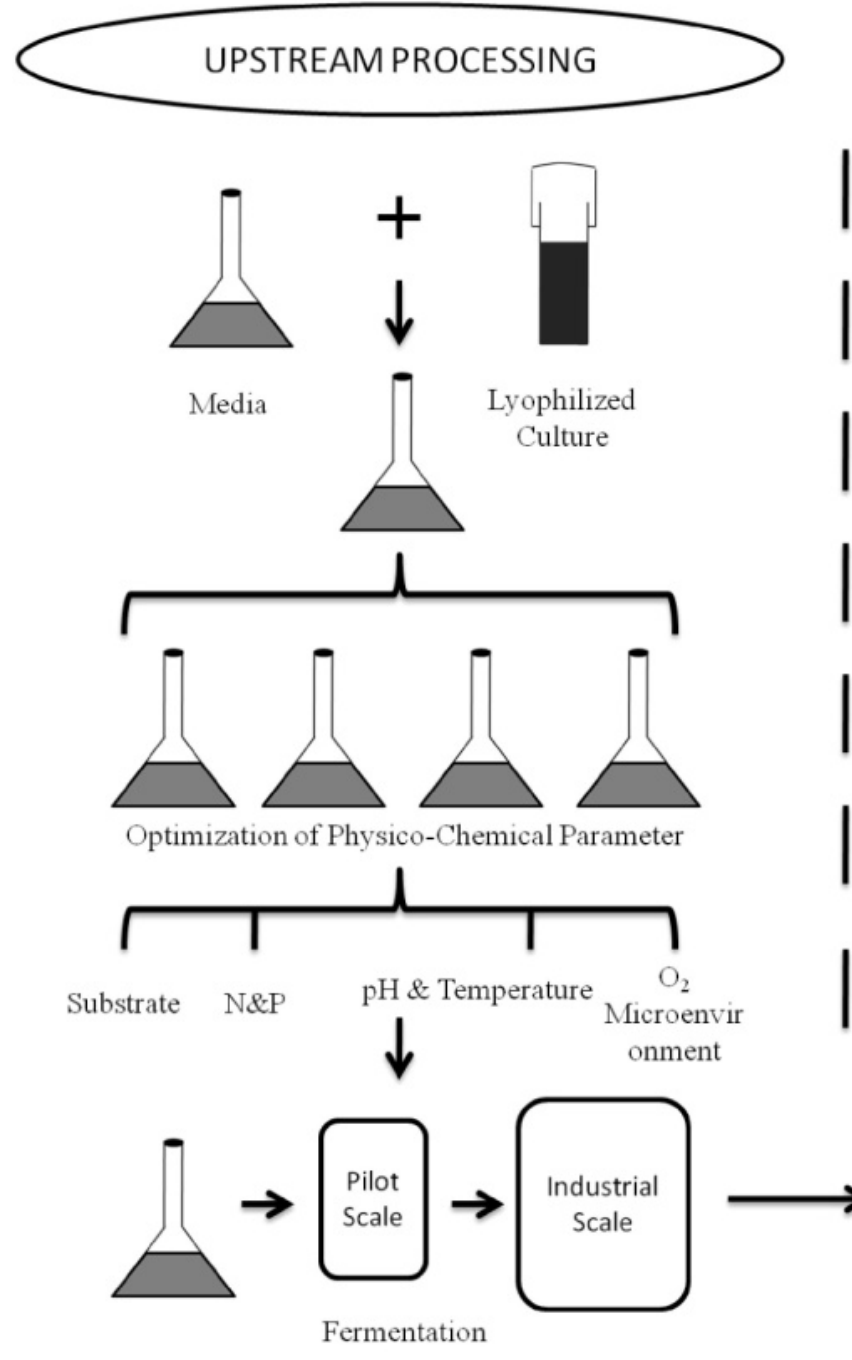

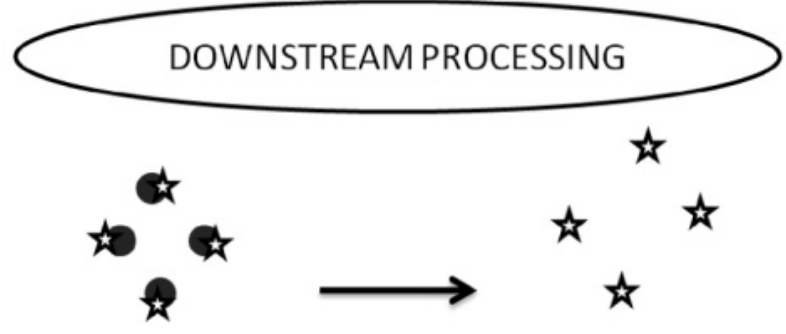

PHA recovery

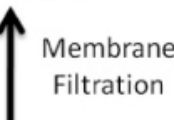

Purified by:

Organic Solvents

Super critical Fluids

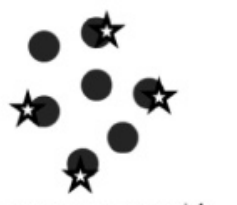

Cell components with PHA separated
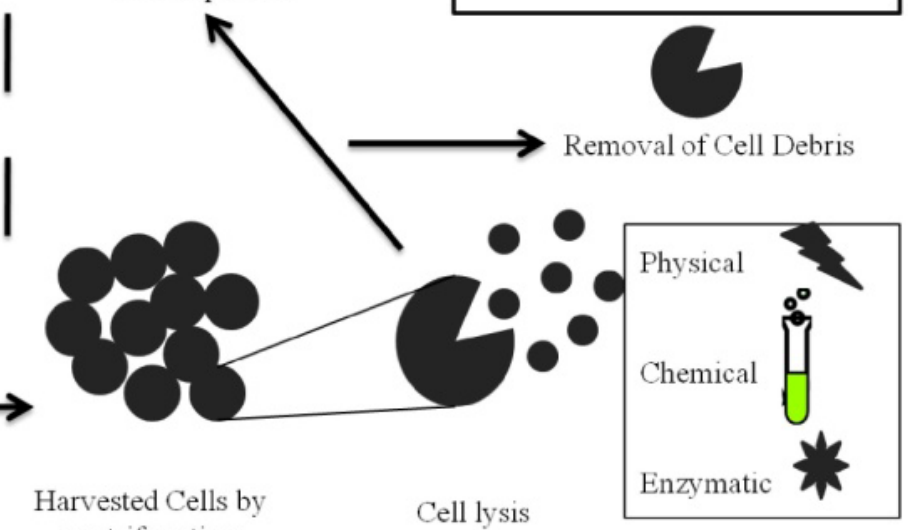
centrifugation

Figure 1: Biopolymer synthesis.

strains, the most commonly studied genera are Bacillus sp, Alcaligenes $s p$, Pseudomonas sp, Aeromonas sp, Rhodopseudomonas sp, Halomonas $s p$, Transgenic Escherichia coli, and Burkholderia sp [7,9]. Table 2 and Table 3 show carbon sources based feeding regimes used by different strains with the PHA Content. The various stress conditions trigger PHA production $[11,12]$; thus, variation in process parameters is required [24-26] to induce the biosynthesis.

\section{Process parameters}

Substrate: Carbon source is an important requisite but is not involved in induction of PHA biosynthesis, although is required for polymer production maximization [54,55]. Glucose is the preferred substrate at industrial scale, many alternatives have also been employed, like sucrose as stated in the research by Azhar et al. of Ain Shams University, Egypt with highest growth and polymer production by Alcaligenes latus [56]. Even a broad spectrum of substrates, namely, starch, sucrose, lactose, maltose, galactose, mannose, mannitol, fructose, glycerol, ethanol, lactic acid, malic acid, acetic acid and butyric acid have been used to compare with glucose [56]. In another report by Poonsuk Prasertsan, the halotolerant bacterial strains Rhodobacter sphaeroides has exhibited maximum growth and polymer production on acetate as a carbon source compared to glucose and fructose [25]. The conclusion deduced glucose, fructose and acetate as good substrates for cellular growth and polymer formation, but a combination of these substrates did not give good results [25].

Nitrogen and phosphate: A research aimed at the optimal requirement of phosphate and nitrogen in the media (specific or complex) to increase the production tested the growth of Aeromonas hydrophila on gluconate enriched MS media containing different phosphate concentrations as (Table 4). It was clearly inferred that a concentration of $11.66 \mathrm{mM}$ phosphate in the media provided a good nutrient deficiency to the bacteria leading to a high PHA concentration [44]. This concentration of phosphate was $1 / 3$ of the normal phosphate concentration used in the media for the bacterial growth. Table 4 illustrates the effect of limiting phosphate concentrations, with nitrogen deficiency in media, on PHA production [44].

Although the nutrient limitation is a prerequisite for PHA production, but, in a recent report on Cupriavidus necator in several nutrition media (Mineral medium, Bonnarme's medium, Mandels' medium and Luria broth Mineral medium, Bonnarme's medium, Mandels' medium and Luria broth) with $10 \mathrm{~g} / \mathrm{l}$ sodium glutamate not 


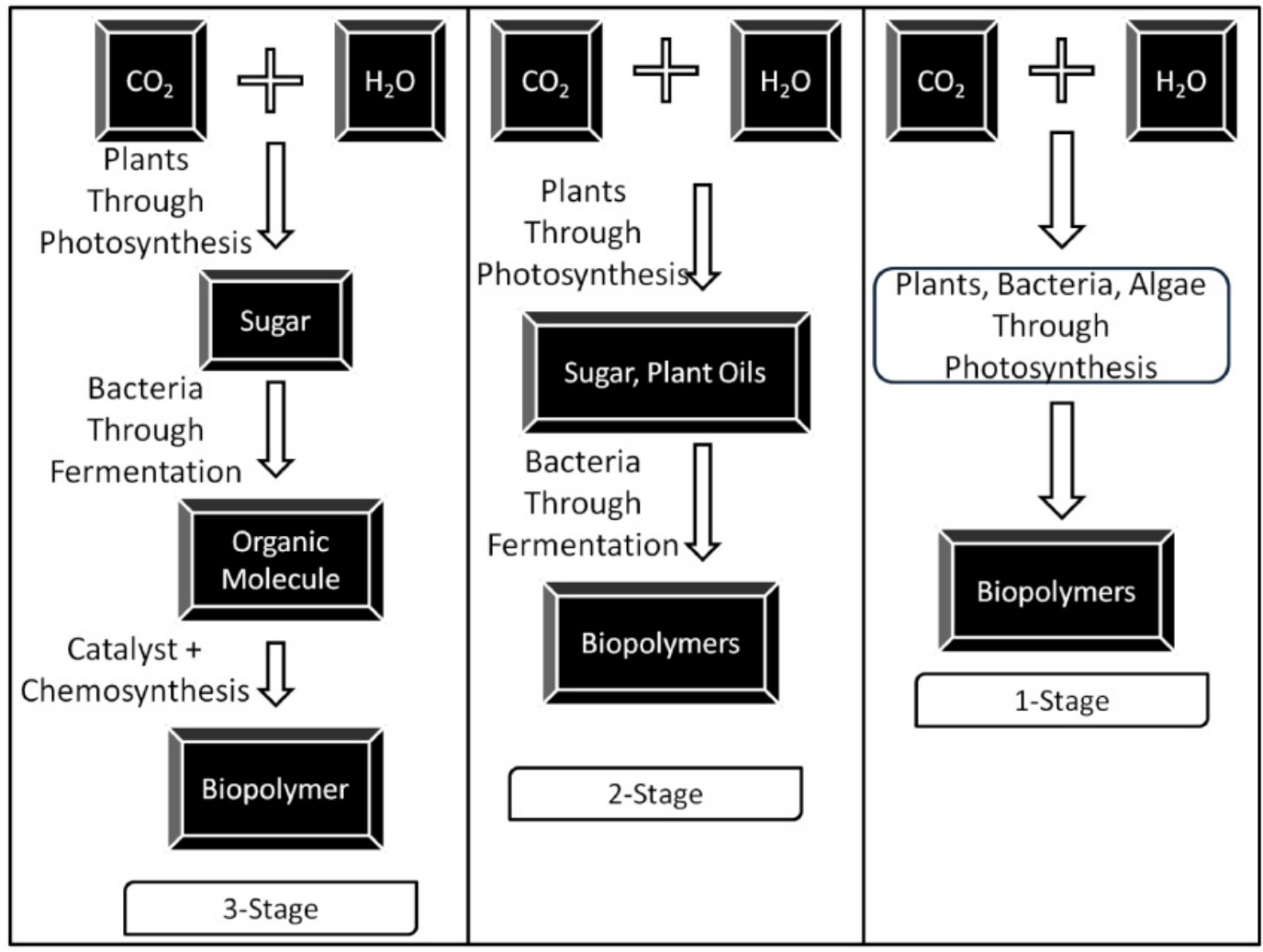

Figure 2: Systems for Biopolymer Synthesis.

only enhanced the overall productivity by 33 times but also decreased the need for limiting nutrients in media [57].

$\mathrm{pH}$ and temperature regimes: The $\mathrm{pH}$ and Temperature optima completely depend on the nature of organisms. According to Palleroni et al. [58] and recent studies done by Wei et al. [26], the optimal $\mathrm{pH}$ range for the growth of bacteria involved in the production of PHAs is 6.0 to $7.5[26,58]$. The temperature requirement for the optimal production is 30 to $37^{\circ} \mathrm{C}$ as reported by Yu-Hong Wei et al. [26]. These are the generalized range for fine bacterial growth.

Oxygen microenvironment: Oxygen limitation is regarded amongst the effective way of enhancing PHA accumulation, involves volumetric oxygen transfer coefficient $\left(k_{L} a\right)$, reducing $\left(k_{L} a\right)$ of the system significantly enhance the PHA yield of the bacterial cell, even at agitation speed of $300 \mathrm{rpm}$, the percentage PHA derivate was $29.8 \%$ whereas it was $50.7 \%$ at $50 \mathrm{rpm}$ [24]. Since $\mathrm{KL}_{\mathrm{a}}$ is lower at low agitation rate, indicates that increasing the oxygen stress enhances PHA production.

\section{Modes of culture}

Four modes of operations are used, these are Batch, Fed batch, Two stage and continuous; although Batch process has been the mode of choice for most of the research and commercial production.

Batch: The batch cultivation is performed from range starting from $100 \mathrm{ml}$ working volume at laboratory scale $[16,28]$ to $15000 \mathrm{~L}$ working volume at industrial scale [59]. Alcaligenes latus (BIOPOL, the first commercially produced biopolymer from Alcaligenes latus [60]), Ralstonia eutropha, Aeromonas hydrophila, Burkholderia sp. and
Pseudomonas putida have been given equal importance for polymer production [9]. Maximum PHA production is reported between 96 to 120 hours in almost all species, where glucose and sucrose have been the substrate of choice (in shake flask batch mode Alcaligenes latus exhibited $45.96 \%$ and $40.14 \%$ PHB content, and in $2 \mathrm{~L}$ reactor it exhibited $56.59 \%$ and $47.53 \%$ PHB content using sucrose and glucose as substrate, respectively), with ammonium sulfate as best nitrogen source $[56,61]$. A $2 \mathrm{~L}$ batch operation yielded maximum PHB content after 80 hours of operation, after which the content decreased (probably due to hydrolysis during stationary phase), suggesting the critical importance of harvesting time [61].

Fed batch: Basic aim of using the fed-batch mode is to increase the biomass with respect to batch mode and is achieved by controlling the intermittent feeding to reduce the substrate inhibition without affecting the growth of the microbe(s). The basic causative agents of inhibition are the organic acids which in high concentration lead to the collapse of the transmembrane $\mathrm{pH}$ gradient of the bacterial cells and a low concentration supports the cell growth and hence PHA accumulation [62]. Two feeding rates for organic acid concentration variation were studied with constant and varying rate on Ralstonia eutropha. Three constant feeding rates of $1.2 \mathrm{~g} / \mathrm{l}, 1.8 \mathrm{~g} / \mathrm{l}$ and $2.5 \mathrm{~g} / \mathrm{l}$ achieved greater biomass(RBM) and PHA content in case of slow feeding rate with zero residual acids, while it ceased at $24^{\text {th }}$ and $36^{\text {th }}$ hours respectively at intermediate feeding, with a residual acid of $2.02 \mathrm{~g} / \mathrm{l}$ and at $18^{\text {th }}$ and $36^{\text {th }}$ hour at fast feeding rate, with a residual acid of $4.02 \mathrm{~g} / \mathrm{l}$ suggesting that cell growth and production could only continue under a low level of residual acids in the medium, while PHAs accumulate at higher acid concentration. Thus it may be considered essential to feed acids during 
Citation: Girdhar A, Bhatia M, Nagpal S, Kanampalliwar A, Tiwari A (2013) Process Parameters for Influencing Polyhydroxyalkanoate Producing Bacterial Factories: An Overview. J Pet Environ Biotechnol 4: 155. doi:10.4172/2157-7463.1000155

Page 4 of 8

\begin{tabular}{|c|c|c|c|}
\hline Strain & Carbon Source Used & $\begin{array}{l}\text { Polymer } \\
\text { Yield }\end{array}$ & References \\
\hline \multirow{4}{*}{ Aeromonas sp. } & Municipal waste water & $11.11 \%$ & \multirow{4}{*}[27]{} \\
\hline & Palm oil mill effluent & $22.97 \%$ & \\
\hline & Glycerol & $19.82 \%$ & \\
\hline & Molasses & $20.09 \%$ & \\
\hline \multirow{4}{*}{ Alcaligenes sp. } & Municipal waste water & $41.11 \%$ & \multirow{4}{*}[27]{} \\
\hline & Palm oil mill effluent & $11.69 \%$ & \\
\hline & Glycerol & $2.33 \%$ & \\
\hline & Molasses & $0.00 \%$ & \\
\hline \multirow{5}{*}{ Bacillus sp. } & 1:1 mixture of $\mathrm{WBH}$ and $\mathrm{RBH}$ & $59 \%$ & [28] \\
\hline & Municipal waste water & $43.95 \%$ & \multirow{4}{*}{ [27] } \\
\hline & Palm oil mill effluent & $58.925 \%$ & \\
\hline & Glycerol & $25.00 \%$ & \\
\hline & Molasses & $48.01 \%$ & \\
\hline \multirow{4}{*}{ Bacillus cereus } & Municipal waste water & $38.07 \%$ & \multirow{4}{*}[27]{} \\
\hline & Palm oil mill effluent & $64.09 \%$ & \\
\hline & Glycerol & $0.00 \%$ & \\
\hline & Molasses & $23.94 \%$ & \\
\hline \multirow{4}{*}{$\begin{array}{c}\text { Bacillus } \\
\text { licheniformis }\end{array}$} & Municipal waste water & $40.97 \%$ & \multirow{4}{*}[27]{} \\
\hline & Palm oil mill effluent & $62.96 \%$ & \\
\hline & Glycerol & $1.69 \%$ & \\
\hline & Molasses & $43 \%$ & \\
\hline \multirow{4}{*}{ B. subtilis } & Municipal waste water & $46.71 \%$ & \multirow{4}{*}{ [27] } \\
\hline & Palm oil mill effluent & $50.00 \%$ & \\
\hline & Glycerol & $18.92 \%$ & \\
\hline & Molasses & $16.13 \%$ & \\
\hline $\begin{array}{c}\text { Bacillus } \\
\text { megaterium }\end{array}$ & Sugarcane molasses & $43 \%$ & [15] \\
\hline $\begin{array}{l}\text { Burkholderia } \\
\text { cepaca }\end{array}$ & Glycerol & $31.35 \%$ & [29] \\
\hline \multirow{4}{*}{$\begin{array}{c}\text { Chromobacterium } \\
\text { sp. }\end{array}$} & Municipal waste water & $25.00 \%$ & \multirow{4}{*}{ [27] } \\
\hline & Palm oil mill effluent & $40.89 \%$ & \\
\hline & Glycerol & $11.86 \%$ & \\
\hline & Molasses & $27.85 \%$ & \\
\hline $\begin{array}{l}\text { Cupriavidus } \\
\text { taiwanensis }\end{array}$ & Gluconic acid & $72 \%$ & {$[26]$} \\
\hline \multirow[b]{2}{*}{ Escherichia coli } & Xylose & $59 \pm 4 \%$ & {$[30]$} \\
\hline & Sodium butyrate & $\begin{array}{l}7.81 \pm \\
0.21 \%\end{array}$ & [31] \\
\hline $\begin{array}{l}\text { Hydrogenophaga } \\
\text { pseudoflava }\end{array}$ & Lactose & $\begin{array}{l}29.8 \pm \\
3.0 \%\end{array}$ & [13] \\
\hline $\begin{array}{c}\text { Haloarcula } \\
\text { hispanica } \\
\text { (previously } \\
\text { deposited as } \\
\text { Halobacterium } \\
\text { hispanicum) }\end{array}$ & YE/Glucose & $2.4 \%$ & [32] \\
\hline $\begin{array}{l}\text { Haloarcula } \\
\text { marismortui }\end{array}$ & YE/Glucose & $21 \%$ & [33] \\
\hline Haloarcula sp. & Glucose & $63 \%$ & [34] \\
\hline Haloarcula japonica & Glucose & $0.5 \%$ & [35] \\
\hline $\begin{array}{l}\text { Halobiforma } \\
\text { haloterrestri }\end{array}$ & Butyric acid & $40 \%$ & [36] \\
\hline H. haloterrestris & YE & $15 \%$ & {$[36]$} \\
\hline $\begin{array}{c}\text { Haloferax } \\
\text { mediterranei }\end{array}$ & YE/Glucose & $17 \%$ & [32] \\
\hline H. mediterranei & Starch & $6.48 \mathrm{~g} / \mathrm{L}$ & [37] \\
\hline Haloferax gibbonsii & YE/Glucose & $1.2 \%$ & [32] \\
\hline Haloferax volcanii & YE/Glucose & $7 \%$ & [32] \\
\hline $\begin{array}{c}\text { Haloterrigena } \\
\text { hispanica }\end{array}$ & YE/Casamino acids & $0.14 \%$ & {$[38,39]$} \\
\hline $\begin{array}{c}\text { Halopiger } \\
\text { aswanensis }\end{array}$ & YE/Na acetate/Butyric acid & $34 \%$ & {$[40,41]$} \\
\hline
\end{tabular}

\begin{tabular}{|c|c|c|c|}
\hline $\begin{array}{c}\text { Pseudomona } \\
\text { oleovorans }\end{array}$ & Gluconic acid & $0.9 \pm 0.1 \%$ & [26] \\
\hline $\begin{array}{c}\text { Pseudomonas } \\
\text { putrefaciens }\end{array}$ & Corn cob & $66.67 \%$ & [14] \\
\hline \multirow{2}{*}{ Pseudomonas sp. } & Municipal Waste Water & $61.05 \%$ & \\
\cline { 2 - 3 } & Palm oil mill effluent & $60.08 \%$ & \multirow{2}{*}{ [27] } \\
\cline { 2 - 3 } & Glycerol & $62.08 \%$ & \\
\hline \multirow{2}{*}{ Proteus mirabilis } & Municipal Waste Water & $0.00 \%$ & \multirow{2}{*}{ [27] } \\
\hline \multirow{2}{*}{ Ralstonia eutropha } & Glycerol & $0.00 \%$ & \\
\hline & Molasses & $0.00 \%$ & [42] \\
\hline & Godium gluconate & $87.03 \%$ & [43] \\
\hline
\end{tabular}

Table 2: Data for carbon sources used by microorganisms for scl-PHA production.

\begin{tabular}{|c|c|c|c|}
\hline Strain & $\begin{array}{l}\text { Carbon Source } \\
\text { Used }\end{array}$ & Polymer Yield & References \\
\hline Aeromonas hydrophila & Gluconate & $15 \%$ & [44] \\
\hline \multirow{8}{*}{ Cupriavidus necator } & $\begin{array}{l}\text { Crude palm kernel oil } \\
(5 \mathrm{~g} / \mathrm{L})\end{array}$ & $77 \pm 3 \%$ & \multirow{8}{*}{ [22] } \\
\hline & $\begin{array}{l}\text { Crude palm kernel oil } \\
(10 \mathrm{~g} / \mathrm{L})\end{array}$ & $82 \pm 2 \%$ & \\
\hline & Jatropha oil & $62 \pm 3 \%$ & \\
\hline & Crude palm oil & $69 \pm 6 \%$ & \\
\hline & Palm olein & $61 \pm 4 \%$ & \\
\hline & Soybean oil & $65 \pm 1 \%$ & \\
\hline & Corn oil & $63 \pm 2 \%$ & \\
\hline & Coconut oil & $70 \pm 3 \%$ & \\
\hline \multirow{5}{*}{ Escherichia coli } & Xylose & $70 \pm 1 \%$ & [30] \\
\hline & Sodium octanoate & $47.3 \pm 5.0 \%$ & \multirow{4}{*}{ [31] } \\
\hline & Decanoic acid & $25.7 \pm 0.9 \%$ & \\
\hline & 10-Undecenoic acid & $41.0 \pm 8.0 \%$ & \\
\hline & Dodecanoic acid & $28.6 \pm 8.0 \%$ & \\
\hline Haloarcula hispanica & YE/Glucose & $17.33 \pm 0.04 \%$ & {$[45]$} \\
\hline Halobacteriumnoricense & Triptone & $0.08 / 0.03 \%$ & {$[46]$} \\
\hline Halococcusdombrowskii & YE/HyCase & $0.15 / 0.01 \%$ & [46] \\
\hline Halococcussalifodinae & YE/HyCase & $0.05 / 0.01 \%$ & [46] \\
\hline \multirow{5}{*}{ Haloferax mediterranei } & Glucose & $27 \%$ & [47] \\
\hline & $\begin{array}{l}\text { ECS (Extruded Corn } \\
\text { Starch) }\end{array}$ & $38.7 \%$ & [47] \\
\hline & $\begin{array}{l}\text { ERB (Extruded Rice } \\
\text { Bran) :ECS }(1: 8)\end{array}$ & $55.6 \%$ & [47] \\
\hline & $\begin{array}{l}\text { Bacto Casa amino } \\
\text { acids/YE }\end{array}$ & $18.21 \pm 1.88 \%$ & [45] \\
\hline & YE/Starch & $24.88 \pm 1.27 \mathrm{~g} / \mathrm{L}$ & {$[45]$} \\
\hline $\begin{array}{l}\text { Hydrogenophaga } \\
\text { pseudoflava }\end{array}$ & Whey (copolymer) & $10.1 \pm 0.9 \%$ & [13] \\
\hline \multirow{16}{*}{ Pseudomonas putida } & Octanoic acid & $49.7 \%$ & [48] \\
\hline & Octanoate & $21 \%$ & \multirow{8}{*}{ [49] } \\
\hline & Glucose & ND & \\
\hline & Acetate & ND & \\
\hline & Pyruvate & ND & \\
\hline & Citrate & ND & \\
\hline & Succinate & ND & \\
\hline & Glucanoate & ND & \\
\hline & fructose & ND & \\
\hline & Dodecanoic acid & $54.5 \%$ & \multirow{2}{*}{ [48] } \\
\hline & Oleic acid & $68.9 \%$ & \\
\hline & Xylose & $20 \%$ & [50] \\
\hline & Nananoic acid & $0.15 \mathrm{~g} / \mathrm{g}$ & \multirow[b]{2}{*}{ [51] } \\
\hline & $\begin{array}{l}\text { NanoicAcid:Glucose } \\
(0.8: 1)\end{array}$ & $50.85 \%$ & \\
\hline & Corn oil & $17.5 \pm 1.4 \%$ & [52] \\
\hline & Glucose & $19 \%$ & [44] \\
\hline
\end{tabular}




\begin{tabular}{|l|l|l|l|}
\hline $\begin{array}{l}\text { Pseudomonas } \\
\text { oleovorans }\end{array}$ & Corn oil & $15.7 \pm 2.5 \%$ & {$[52]$} \\
\hline $\begin{array}{l}\text { Pseudomonas } \\
\text { chlororaphis }\end{array}$ & Corn oil & $39.5 \pm 0.8$ & {$[52]$} \\
\hline $\begin{array}{l}\text { Pseudomonas G101 } \\
\text { Natronobacterium } \\
\text { gregoryi }\end{array}$ & $\begin{array}{l}\text { Waste frying rapseed } \\
\text { oil }\end{array}$ & $20 \%$ & {$[53]$} \\
\hline Sinorhizobiummeliloti & Rice bran hydrolysate & $48.32 \%$ & {$[4]$} \\
\hline
\end{tabular}

Table 3: Data for carbon sources used by microorganisms for mcl-PHA production.

\begin{tabular}{|c|c|c|c|}
\hline Concentration & $\begin{array}{c}\mathrm{Amount} \\
\mathrm{Na}_{2} \mathrm{HPO}_{4} \cdot 12 \mathrm{H}_{2} \mathrm{O} \\
(\mathrm{g} / \mathrm{l})\end{array}$ & $\begin{array}{c}\mathrm{Amount}^{2} \\
\mathrm{KH}_{2} \mathrm{PO}_{4}(\mathrm{~g} / \mathrm{l})\end{array}$ & $\begin{array}{c}\mathrm{PHA} \text { concentration } \\
(\%, w / w)\end{array}$ \\
\hline Normal phosphate $\mathbf{( 3 5 m M )}$ & 9 & 1.5 & $4.6 \pm 0.6$ \\
\hline 2/3 phosphate $\mathbf{( 2 3 . 3 5} \mathbf{~ m M )}$ & 6 & 1 & $5.5 \pm 0.5$ \\
\hline $\mathbf{1 / 3}$ phosphate (11.66 $\mathbf{m M})$ & 3 & 0.5 & $10.2 \pm 0.5$ \\
\hline
\end{tabular}

Table 4: Effect of limiting $\mathrm{P}$ and $\mathrm{N}$ concentrations on $\mathrm{PHA}$ production [44].

the cell growth phase, followed by gradually decreasing the flow rate to maintain a lower residual concentration of about $2 \mathrm{~g} / \mathrm{l}$. This strategy came out to be successful with the Dry Cell Weight (DCW) and PHA contents as $14.35 \mathrm{~g} / \mathrm{L}$ and $6.89 \mathrm{~g} / \mathrm{L}$ respectively at the end of $42^{\text {nd }}$ hour [62]. $\mathrm{pH}$-stat mode provide randomly variable rate of organic acids, which worked on the principle of acid adjustment/pH control and is successful if the $\mathrm{pH}$ of the system varies with the growth of the bacteria. The $\mathrm{pH}$ variation is adjusted by organic acids rather than $\mathrm{HCl} / \mathrm{NaOH}$ leading to a random feeding of organic acids, which caused random feeding leading to less effective PHA production and DCW. In reference, a more careful feed rate control can further modulated for improvement in cell growth and PHA production.

Continuous: Continuous fermentation technology has got advantage of maintaining constant nutrient environment and is useful to study the effect of nutrient limitation on the bacterial growth and productivity in a quick and real time manner [63]. In fact, the documented reports are aimed at studying the effect of limiting the concentration of various nutrients. In a recent example, the metabolic response of $P$. putida KT2442 producing high levels of PHA under single- and multiple-nutrient-limited growth, with chemostat mode has been reported [64]. At the industrial level, continuous mode could prove very useful owing to continuous harvesting of the product, coupled with the ability to tweak the nutrient concentration as per the requirement; although the stringency of sterile environment and a check on mutability of the producing strain becomes obligatory under continuous mode, when compared to the ease of batch mode.
Two - stage batch culture as the best method for $\mathrm{PHB}$ production: The two-stage fermentation involves supply of nutrients to the culture in two different stages and composition. Thus, becomes handy for possessing the nutrient limitation, a prerequisite for PHA production [9]. In the first stage, culture is fed with simple carbon sources such as glucose or fructose and other essential nutrients to make sure that cells grow at high specific growth rate and lead to a higher cell biomass yield, whereas in the second stage, supply of essential nutrient such as nitrogen is limited as a trigger to initiate the biosynthesis [56]. A volumetric PHA productivity of $1.06 \mathrm{~g} \mathrm{~L}^{-1} \mathrm{~h}^{-1}$ was obtained by Twostage continuous mode of Pseudomonas oleovorans culture [65].

\section{Downstream Processing}

All the bacterial species reported to produce polyhydroxyalkanoates, accumulate them intracellularly in the form of granules, as carbon and energy reserves [44,59]. It is thus apparent, that the downstream processing chain of PHAs begins from cell lysis of the biomass separated from the medium by centrifugation, so as to expose the cell trapped product [66]. There are many techniques used for the purpose, Table 5 describes a few of these.

\section{Recovery}

The PHAs are present in the cell debris after the cell lysis and centrifugation, which can be recovered with a good efficiency using different solvents like cold methanol, chloroform etc [77]. This leaves a dull white precipitate behind; further purification of the product is done by membrane filtration, which helps in segregating PHAs from other small biomolecules still present in the extract. A study with nonhalogenated solvents for recovery from $R$. eutropha has shown to give high purity (upto 99\%) and have proved potentiality of ethyl acetate and methyl isobutyl ketone to replace halogenated solvent, chloroform, with cost reduction benefits [78]. In a research, $0.1 \mu \mathrm{m}$ ceramic tubular membranes have shown high separation efficiency owing to their chemical inertness and resistance to $\mathrm{pH}$, temperature and concentration changes [77]. But polyethersulfone polymeric flat plate membrane modules are becoming the choices of the day because of their 5-10 times less cost than ceramic membranes and ability to retain even the smallest PHA granule. However, membranes like polyethersulfone come with an inherent disadvantage of limited life span and need to be replaced once in a year or two. It must be noted that the ultra-filtration carried out to separate the PHAs is operated in a cross flow regime, which avoids the blocking of the membranes and ensures continuous operation for long time [77]. The amount of product recovered in form of filtrate is then determined using Gas Chromatography to confirm

\begin{tabular}{|c|c|c|c|c|}
\hline Classes & Techniques & Acting Principle & Microorganism & Reference \\
\hline \multirow{4}{*}{$\begin{array}{l}\text { Physical/ } \\
\text { MechanicalDisruption }\end{array}$} & Thermolysis & $\begin{array}{l}\text { Disruption of Cell wall by the affect of ionic strength, } \mathrm{pH} \text { and temperature } \\
\text { with chelating agent }\end{array}$ & & {$[67,68]$} \\
\hline & Ultrasonication & Ultrasonic waves, followed by centrifugation & Bacillus flexus & [68] \\
\hline & Bead Mill & $\begin{array}{l}\text { Grinding cylinder containing beads made of wear resistant materials like } \\
\text { glass, alumina, titanium carbide, zirconium oxide and zirconium silicate is } \\
\text { driven by motor }\end{array}$ & Alcaligenes latus & {$[60,67,69]$} \\
\hline & $\begin{array}{l}\text { High Pressure } \\
\text { Homogenizer }\end{array}$ & $\begin{array}{l}\text { Disrupter fitted with a displacement pump monitors the pressure and a } \\
\text { discharge valve to homogenize the solution pushed through pump }\end{array}$ & Gram Negative Bacteria & [70] \\
\hline \multirow{3}{*}{ Chemical Disruption } & Alkali Treatment & Exposure to basic pH (mild alkaline hydrolysis) & Bacillus flexus & [69] \\
\hline & Detergent Solubilization & $\begin{array}{l}\text { Detergents like SDS, CTAB, Triton X 100, Saponins, Tween } 20 \text { and } \\
\text { Tween } 80 \text { etc, are used }\end{array}$ & Ralstonia eutropha & {$[67,71,72]$} \\
\hline & Cell Wall Permeabilisation & $\begin{array}{l}\text { Organic solvents like toluene, acetone, chloroform and ethylene } \\
\text { carbonate are used, followed by non-solvent precipitation }\end{array}$ & $\begin{array}{l}\text { Bacillus cereus SPV and } \\
\text { Cupriavidus necator, } \\
\text { respectively. }\end{array}$ & {$[73,74]$} \\
\hline \multicolumn{2}{|l|}{ Enzymatic Disruption } & Lytic enzymes in medium with detergent or chelating agent & Cupriavidus necator & {$[75,76]$} \\
\hline
\end{tabular}




\begin{tabular}{|l|l|l|}
\hline Parameters & Synthetic Plastics & Biodegradable Plastics \\
\hline \multirow{5}{*}{ Synthesis } & Crude oil & Microorganism \\
\hline & Flash distillation & Waste carbon sources \\
\cline { 2 - 3 } & Column distillation & Culturing \\
\hline & Cracking (use of catalyst) & Biomass separation \\
\hline \multirow{5}{*}{ Degradation } & Polymerization & Polymer recovery \\
\cline { 2 - 3 } & Heat required for every step & $\begin{array}{l}\text { Heat required for film } \\
\text { preparation and drying }\end{array}$ \\
\hline & Ethylene, $\mathrm{CO}_{2}, \mathrm{CH}_{4}$ production & $\begin{array}{l}\text { Biological compounds are } \\
\text { produced }\end{array}$ \\
\hline & Toxic & Non-toxic \\
\hline & Never degrade & Take days to months \\
\hline
\end{tabular}

Table 6: Factors deciding cost.

the percentage of recovery [43]. Quantification can be done by NMR [79], Flow Cytometry [80] etc.

\section{Cost}

The major factor of concern is the cost of the produced biomaterial i.e. PHA. The production cost is contributed by various factors. The process parameters are involved in upstream cost whereas the down streaming involves the cost of solvents used and the other purification strategies. The Table 6 illustrates parameters involved in cost of production and degradation through biological means. Processing cost in generally $20 \%$ of the total cost.

\section{Conclusion}

The growing environmental pollution is becoming a global concern, where synthetic plastics contribute to a great extent due to their nondegradability. The bioplastics can be regarded as a working alternative to conquer the conundrum. From all the classes of bioplastics, PHA has shown to have analogous properties with biodegradability. Thus, PHA can be looked forward as an alternate to synthetic plastics as they require natural sources for synthesis like Bacteria, that have come as an effective way for commercial production, Ralstonia eutropha is amongst the best producers. Being promiscuous in nature, their production involves certain process parameters to be optimized both at laboratory and industrial scale, where the optimum $\mathrm{pH}$ and temperature range depends on the microorganism used in the synthesis. Further the $\mathrm{O}_{2}$ stress enhances the production. The mode of fermentation is responsible for influencing the biomass yield and accumulation of the product. Not to overlook the Cost factor, which can be reduced by various alternatives to novel carbon sources, but to attain a good yield and commercialization with these alternatives still remain a challenge.

\section{References}

1. Cavalheiro JMBT, de Almeida MCMD, Grandfils C, da Fonseca MMR (2009) Poly(3-hydroxybutyrate) production by Cupriavidus necator using waste glycerol. Process Biochem 44: 509-515.

2. Shrivastav A, Mishra SK, Pancha I, Jain D, Bhattacharya S, et al. (2011) Biodegradability studies of polyhydroxyalkanoate (PHA) film produced by a marine bacteria using Jatropha biodiesel byproduct as a substrate. World $\mathrm{J}$ Microb Biot 27: 1531-1541.

3. Ojumu TV, Yu J, Solomon Bo (2004) Production of Polyhydroxyalkanoates, a bacterial biodegradable polymer. African Journal of Biotechnology 3: 18-24.

4. Devi ES, Vijayendra SVN, Shamala TR (2012) Exploration of rice bran, an agro-industry residue, for the production of intra- and extra-cellular polymers by Sinorhizobium meliloti MTCC 100. Biocatalysis and Agricultural Biotechnology 1: 80-84.

5. Lemoigne M (1926) Produits de dehydration et de polymerisation de l'acide ß-oxobutyrique. Bull Soc Chim Biol 8: 770-782.

6. Zhu C, Chiu S, Nakas JP, Nomura CT (2013) Bioplastics from waste glycerol derived from biodiesel industry. J Appl Polym Sci 130: 1-13

7. Setyawaty R, Setiadi T, Katayama-Hirayama K, Kaneko H, Hirayama K (2012) Polyhydroxyalkanoate (PHA) production from tapioca industrial wastewater treatment: Influence of operating conditions on PHA content. Sustain Environ Res 22: 123-127.

8. Jendrossek D (2009) Polyhydroxyalkanoate granules are complex subcellular organelles (carbonosomes). J Bacteriol 191: 3195-3202.

9. Khanna S, Srivastava AK (2005) Recent advances in microbial polyhydroxyalkanoates. Process Biochem 40: 607-619.

10. Verlinden RA, Hill DJ, Kenward MA, Williams CD, Radecka I (2007) Bacteria synthesis of biodegradable polyhydroxyalkanoates. J Appl Microbiol 102: 14371449.

11. Foster LJ (2007) Biosynthesis, properties and potential of natural-synthetic hybrids of polyhydroxyalkanoates and polyethylene glycols. Appl Microbiol Biotechnol 75: 1241-1247.

12. Kadouri D, Jurkevitch E, Okon Y, Castro-Sowinski S (2005) Ecological and agricultural significance of bacterial polyhydroxyalkanoates. Crit Rev Microbiol 31: $55-67$

13. Povolo S, Romanelli MG, Basaglia M, Ilieva VI, Corti A, et al. (2013) Polyhydroxyalkanoate biosynthesis by Hydrogenophaga pseudoflava DSM1034 from structurally unrelated carbon sources. N Biotechnol 30: 629634

14. Ogunjobi AA, Ogundele AO, Fagade OE (2011) Production of polyhydroxyalkanoates by Pseudomonas putrefaciens from cheap and renewable carbon substrates. Electronic Journal of Environmental, Agricultural and Food Chemistry 10: 2806-2815.

15. Chaijamrus S, Udpuay N (2008) Production and Characterization of Polyhydroxybutyrate from Molasses and Corn Steep Liquor produced by Bacillus megaterium ATCC 6748. Agricultural Engineering International: the CIGR Ejournal.

16. Baei MS, Najafpour GD, Younesi H, Tabandeh F, Eisazadeh H (2009) Poly(3 hydroxybutyrate) Synthesis by Cupriavidus necator DSMZ 545 Utilizing Various Carbon Sources. World Applied Sciences Journa 7: 157-161.

17. Solaiman DK, Ashby RD, Foglia TA, Marmer WN (2006) Conversion of agricultural feedstock and coproducts into poly(hydroxyalkanoates). Appl Microbiol Biotechnol 71: 783-789.

18. Omar FN, Rahman NAA, Hafid HS, Mumtaz T, Yee PL, et al. (2011) Utilization of kitchen waste for the production of green thermoplastic polyhydroxybutyrate (PHB) by Cupriavidus necator CCGUG 52238. African Journal of Microbiology Research 5: 2873-2879.

19. Sharmila T, Meenakshi SA, Kandhymathy K, Bharathidasan R, Mahalingam $R$, et al. (2011) Screening And Characterisation Of Polyhydroxybutyrate Producing Bacteria From Sugar Industry Effluents. World Journal of Science and Technology 1.

20. Verlinden RA, Hill DJ, Kenward MA, Williams CD, Piotrowska-Seget Z, et al. (2011) Production of polyhydroxyalkanoates from waste frying oil by Cupriavidus necator. AMB Express 1: 11.

21. Budde CF, Riedel SL, HÃ/4bner F, Risch S, PopoviÄ $\ddagger$ MK, et al. (2011) Growth and polyhydroxybutyrate production by Ralstonia eutropha in emulsified plant oil medium. Appl Microbiol Biotechnol 89: 1611-1619.

22. Wong YM, Brigham CJ, Rha C, Sinskey AJ, Sudesh K (2012) Biosynthesis and characterization of polyhydroxyalkanoate containing high 3-hydroxyhexanoate monomer fraction from crude palm kernel oil by recombinant Cupriavidus necator. Bioresour Technol 121: 320-327.

23. Riedel SL, Bader J, Brigham CJ, Budde CF, Yusof ZA, et al. (2012) Production of poly(3-hydroxybutyrate-co-3-hydroxyhexanoate) by Ralstonia eutropha in high cell density palm oil fermentations. Biotechnol Bioeng 109: 74-83.

24. Pozo C, Martínez-Toledo MV, Rodelas B, González-López J (2002) Effects of culture conditions on the production of polyhydroxyalkanoates by Azotobacter chroococcum $\mathrm{H} 23$ in media containing a high concentration of alpechín (wastewater from olive oil mills) as primary carbon source. J Biotechnol 97: 125-131.

25. Sangkharak K, Prasertsan P (2008) Nutrient optimization for production of polyhydroxybutyrate from halotolerant photosynthetic bacteria cultivated under aerobic-dark condition. Electron J Biotechnol 11: 83-94. 
Citation: Girdhar A, Bhatia M, Nagpal S, Kanampalliwar A, Tiwari A (2013) Process Parameters for Influencing Polyhydroxyalkanoate Producing Bacterial Factories: An Overview. J Pet Environ Biotechnol 4: 155. doi:10.4172/2157-7463.1000155

Page 7 of 8

26. Wei YH, Chen WC, Huang CK, Wu HS, Sun YM, et al. (2011) Screening and Evaluation of Polyhydroxybutyrate-Producing Strains from Indigenous Isolate Cupriavidus taiwanensis Strains. Int J Mol Sci 12: 252-265.

27. Sangkharak K, Prasertsan P (2012) Screening and identification of polyhydroxyalkanoates producing bacteria and biochemical characterization of their possible application. J Gen Appl Microbiol 58: 173-182.

28. Shamala TR, Vijayendra SV, Joshi GJ (2012) Agro-industrial residues and starch for growth and co-production of polyhydroxyalkanoate copolymer and Ît-amylase by Bacillus sp. CFR-67. Braz J Microbiol 43: 1094-1102.

29. Zhu C, Nomura CT, Perrotta JA, Stipanovic AJ, Nakas JP (2010) Production and characterization of poly-3-hydroxybutyrate from biodiesel-glycerol by Burkholderia cepacia ATCC 17759. Biotechnol Prog 26: 424-430.

30. Nduko JM, Matsumoto K, Ooi T, Taguchi S (2013) Effectiveness of xylose utilization for high yield production of lactate-enriched P(lactate-co-3hydroxybutyrate) using a lactate-overproducing strain of Escherichia coli and an evolved lactate-polymerizing enzyme. Metab Eng 15: 159-166.

31. Tappel RC, Wang Q, Nomura CT (2012) Precise control of repeating unit composition in biodegradable poly(3-hydroxyalkanoate) polymers synthesized by Escherichia coli. J Biosci Bioeng 113: 480-486.

32. Kumar AS, Mody K, Jha B (2007) Bacterial exopolysaccharides--a perception. J Basic Microbiol 47: 103-117.

33. Han J, Lu Q, Zhou L, Zhou J, Xiang H (2007) Molecular Characterization of the phaECHm Genes, Required for Biosynthesis of Poly(3-Hydroxybutyrate) in the Extremely Halophilic Archaeon Haloarcula marismortui. Appl Environ Microbiol 73: 6058-6065.

34. Taran M, Amirkhani H (2010) Strategies of poly(3-hydroxybutyrate) synthesis by Haloarcula sp. IRU1 utilizing glucose as carbon source: Optimization of culture conditions by Taguchi methodology. Int J Biol Macromol 47: 632-634.

35. Nicolaus B, Lama L, Esposito E, Manca MC, Improta R, et al. (1999) Haloarcula spp able to biosynthesize exo- and endopolymers. J Ind Microbiol Biot 23: 489496.

36. Hezayen FF, Tindall BJ, Steinbüchel A, Rehm BHA (2002) Characterization of a novel halophilic archaeon, Halobiforma haloterrestris gen. nov., sp. nov., and transfer of Natronobacterium nitratireducens to Halobiforma nitratireducens comb. nov. Int J Syst Evol Micr 52: 2271-2280.

37. Lillo JG, Rodriguez-Valera F (1990) Effects of Culture Conditions on Poly(betaHydroxybutyric Acid) Production by Haloferax mediterranei. Appl Environ Microbiol 56: 2517-2521.

38. Romano I, Poli A, Finore I, Huertas FJ, Gambacorta A, et al. (2007) Haloterrigena hispanica sp. nov., an extremely halophilic archaeon from Fuente de Piedra, southern Spain. Int J Syst Evol Microbiol 57: 1499-1503.

39. Donato PD, Fiorentino G, Anzelmo G, Tommonaro G, Nicolaus B, et al. (2011) Re-Use of Vegetable Wastes as Cheap Substrates for Extremophile Biomass Production. Waste and Biomass Valorization 2: 103-111.

40. Hezayen FF, Rehm BH, Eberhardt R, Steinbüchel A (2000) Polymer production by two newly isolated extremely halophilic archaea: application of a nove corrosion-resistant bioreactor. Appl Microbiol Biotechnol 54: 319-325.

41. Hezayen FF, Gutiérrez MC, Steinbüchel A, Tindall BJ, Rehm BH (2010) Halopiger aswanensis sp. nov., a polymer-producing and extremely halophilic archaeon isolated from hypersaline soil. Int J Syst Evol Microbiol 60: 633-637.

42. Moreno N, Gutiérrez I, Malagón D, Grosso V, Revelo D, et al. (2007) Bioprospecting and characterization of poly-bhydroxyalkanoate (PHAs) producing bacteria isolated from Colombian sugarcane producing areas. African Journal of Biotechnology 6.

43. Heinrich D, Madkour MH, Al-Ghamdi MA, Shabbaj II, Steinbüchel A (2012) Large scale extraction of poly(3-hydroxybutyrate) from Ralstonia eutropha $\mathrm{H} 16$ using sodium hypochlorite. AMB Express 2: 59

44. Quu YZ, Han J, Guo JJ, Chen GQ (2005) Production of poly(3-hydroxybutyrateco-3-hydroxyhexanoate) from gluconate and glucose by recombinan Aeromonas hydrophila and Pseudomonas putida. Biotechnol Lett 27: 13811386 .

45. Lu Q, Han J, Zhou L, Zhou J, Xiang H (2008) Genetic and biochemical characterization of the poly(3-hydroxybutyrate-co-3-hydroxyvalerate) synthase in Haloferax mediterranei. J Bacteriol 190: 4173-4180.

46. Legat A, Gruber C, Zangger K, Wanner G, Stan-Lotter H (2010) Identification of polyhydroxyalkanoates in Halococcus and other haloarchaeal species. App Microbiol Biotechnol 87: 1119-1127.

47. Huang TY, Duan KJ, Huang SY, Chen CW (2006) Production of polyhydroxyalkanoates from inexpensive extruded rice bran and starch by Haloferax mediterranei. J Ind Microbiol Biotechnol 33: 701-706.

48. Gumel AM, Annuar MS, Heidelberg T (2012) Biosynthesis and characterization of polyhydroxyalkanoates copolymers produced by Pseudomonas putida Bet001 isolated from palm oil mill effluent. PLoS One 7: e45214.

49. Escapa IF, del Cerro C, García JL, Prieto MA (2013) The role of GlpR represso in Pseudomonas putida KT2440 growth and PHA production from glycerol Environ Microbiol 15: 93-110.

50. Le Meur S, Zinn M, Egli T, Thöny-Meyer L, Ren Q (2012) Production of mediumchain-length polyhydroxyalkanoates by sequential feeding of xylose and octanoic acid in engineered Pseudomonas putida KT2440. BMC Biotechnol 12: 53.

51. Jiang X, Sun Z, Marchessault RH, Ramsay JA, Ramsay BA (2012) Biosynthesis and properties of medium-chain-length polyhydroxyalkanoates with enriched content of the dominant monomer. Biomacromolecules 13: 2926-2932.

52. Chung MG, Rhee YH (2012) Overexpression of the (R)-specific enoyl-CoA hydratase gene from Pseudomonas chlororaphis HS21 in Pseudomonas strains for the biosynthesis of polyhydroxyalkanoates of altered monomer composition. Biosci Biotechnol Biochem 76: 613-616.

53. Mozejko J, Wilke A, PrzybyÅ,ek G, Ciesielski S (2012) Mcl-PHAs produced by Pseudomonas sp. GI01 using fed-batch cultivation with waste rapeseed oil as carbon source. J Microbiol Biotechnol 22: 371-377.

54. Park SJ, Kim TW, Kim MK, Lee SY, Lim SC (2012) Advanced bacteria polyhydroxyalkanoates: towards a versatile and sustainable platform for unnatural tailor-made polyesters. Biotechnol Adv 30: 1196-1206.

55. Saxena A, Tiwari A (2011) Polyhydroxyalkonates: Green Plastics of the Future International Journal of Biomedical and Advance Research 2: 356-367.

56. El-sayed AA, Abdel Hafez AM, Hemmat, Abdelhady M, Khodair TA (2009) Poduction of Polyhydroxybutyrate (PHB) Using Batch and Two-stage Batch Culture Strategies. Australian Journal of Basic and Applied Sciences 3: 617 627

57. Berezina N (2013) Novel approach for productivity enhancement of polyhydroxyalkanoates (PHA) production by Cupriavidus necator DSM 545. N Biotechnol 30: 192-195.

58. Palleroni NJ, Palleroni AV (1978) Alcaligenes latus, a new species of hydrogenutilizing bacteria. Int J Syst Bacteriol 28: 416-424.

59. Chen GGQ (2010) Plastics from Bacteria: Natural Functions and Applications (Microbiology Monographs). Springer USA.

60. Tamer IM, Moo-Young M, Chisti Y (1998) Disruption of Alcaligenes latus for Recovery of Poly( $\beta$-hydroxybutyric acid): Comparison of High-Pressure Homogenization, Bead Milling, and Chemically Induced Lysis. Ind Eng Chem Res 37: 1807-1814.

61. Azhar ESA, Abdelhady HM, Hafez AMA, Khodair TA (2009) Batch production of polyhydroxybutyrate (PHB) by Ralstonia eutropha and Alcaligenes latus using bioreactor different culture strategies. Journal of Applied Sciences Research 5: 556-564.

62. Yan Q, Du G, Chen J (2003) Biosynthesis of polyhydroxyalkanoates (PHAs) with continuous feeding of mixed organic acids as carbon sources by Ralstonia eutropha. Process Biochem 39: 387-391.

63. Hoskisson PA, Hobbs G (2005) Continuous culture--making a comeback? Microbiology 151: 3153-3159.

64. Poblete-Castro I, Escapa IF, Jäger C, Puchalka J, Lam CM, et al. (2012) The metabolic response of $P$. putida KT2442 producing high levels of polyhydroxyalkanoate under single- and multiple-nutrient-limited growth highlights from a multi-level omics approach. Microb Cell Fact 11: 34.

65. Jung K, Hazenberg W, Prieto M, Witholt B (2001) Two-stage continuous process development for the production of medium-chain-length poly(3hydroxyalkanoates). Biotechnol Bioeng 72: 19-24.

66. Preethi R, Sasikala P, Aravind J (2012) Microbial production of polyhydroxyalkanoate (PHA) utilizing fruit waste as a substrate. Research in Biotechnology 3: 61-69. 
Citation: Girdhar A, Bhatia M, Nagpal S, Kanampalliwar A, Tiwari A (2013) Process Parameters for Influencing Polyhydroxyalkanoate Producing Bacterial Factories: An Overview. J Pet Environ Biotechnol 4: 155. doi:10.4172/2157-7463.1000155

Page 8 of 8

67. Sivasankar B (2005) Biosperations: Principles and Techniques. PHI Learning New Delhi India.

68. Divyashree MS, Shamala TR, Rastogi NK (2009) Isolation of polyhydroxyalkanoate from hydrolyzed cells of Bacillus flexus using aqueous two-phase system containing polyethylene glycol and phosphate. Biotechnology and Bioprocess Engineering 14: 482-489.

69. Kunasundari B, Sudesh K (2011) Isolation and recovery of microbial polyhydroxyalkanoates. express polym lett 5: 620-634.

70. Diels AM, Michiels CW (2006) High-pressure homogenization as a non-thermal technique for the inactivation of microorganisms. Crit Rev Microbiol 32: 201 216.

71. Choi J, Lee SY (1999) Efficient and economical recovery of poly(3hydroxybutyrate) from recombinant Escherichia coli by simple digestion with chemicals. Biotechnol Bioeng 62: 546-553.

72. Yang YH, Brigham C, Willis L, Rha C, Sinskey A (2011) Improved detergentbased recovery of polyhydroxyalkanoates (PHAs). Biotechnol Lett 33: 937-942.

73. Valappil SP, Misra SK, Boccaccini AR, Keshavarz T, Bucke C, et al. (2007) Large-scale production and efficient recovery of PHB with desirable material properties, from the newly characterised Bacillus cereus SPV. J Biotechnol 132: 251-258.

74. Fiorese ML, Freitas F, Pais J, Ramos AM, de Aragão GMF, et al. (2009) Recovery of polyhydroxybutyrate (PHB) from Cupriavidus necator biomass by solvent extraction with 1,2-propylene carbonate. Engineering in Life Sciences 9: 454-461.

75. Kathiresan Y, Aroua MK, Ramachandran KB (2011) Chemical Characterization of medium-chain-length polyhydroxyalkanoates (PHAs) recovered by enzymatic treatment and ultrafiltration. J Chem Technol Biot 82: 847-855.

76. Kapritchkoff FM, Viotti AP, Alli RC, Zuccolo M, Pradella JG, et al. (2006) Enzymatic recovery and purification of polyhydroxybutyrate produced by Ralstonia eutropha. J Biotechnol 122: 453-462.

77. Yasotha K, Aroua MK, Ramachandran KB, Tan IKP (2006) Recovery of medium-chain-length polyhydroxyalkanoates (PHAs) through enzymatic digestion treatments and ultrafiltration. Biochem Eng J 30: 260-268.

78. Riedel SL, Brigham CJ, Budde CF, Bader J, Rha C, et al. (2013) Recovery of poly(3-hydroxybutyrate-co-3-hydroxyhexanoate) from Ralstonia eutropha cultures with non-halogenated solvents. Biotechnol Bioeng 110: 461-470.

79. Cavalheiro JM, Raposo RS, de Almeida MC, Cesário MT, Sevrin C, et al. (2012) Effect of cultivation parameters on the production of poly(3-hydroxybutyrateco-4-hydroxybutyrate) and poly(3-hydroxybutyrate-4-hydroxybutyrate-3hydroxyvalerate) by Cupriavidus necator using waste glycerol. Bioresour Technol 111: 391-397.

80. Saranya V, Poornimakkani, Krishnakumari MS, Suguna P, Binuramesh C, et al. (2012) Quantification of intracellular polyhydroxyalkanoates by virtue of personalized flow cytometry protocol. Curr Microbiol 65: 589-594. 